\title{
Agrobacterium tumefaciens: a natural tool for plant transformation
}

\author{
Gustavo A. de la Riva ${ }^{1}$ \\ Laboratory of Environmental Biotechnology. Plant Division. Centre for Genetic Engineering and Biotechnology (CIGB). \\ P.O.Box 6162, 10600 Havana, Cuba \\ Fax: (53-7) 218070, (53-7) 336008 \\ E-mail: Gustavo.Riva@cigb.edu.cu \\ Joel González-Cabrera \\ Laboratory of Environmental Biotechnology. Plant Division. Centre for Genetic Engineering and Biotechnology (CIGB). \\ P.O.Box 6162, 10600 Havana, Cuba \\ Fax: (53-7) 218070, (53-7) 336008 \\ E-mail: CryLab@cigb.edu.cu \\ Roberto Vázquez-Padrón \\ Laboratory of Environmental Biotechnology. Plant Division. Centre for Genetic Engineering and Biotechnology (CIGB). \\ P.O.Box 6162, 10600 Havana, Cuba \\ Fax: (53-7) 218070, (53-7) 336008 \\ E-mail: CryLab@cigb.edu.cu \\ Camilo Ayra-Pardo \\ Laboratory of Environmental Biotechnology. Plant Division. Centre for Genetic Engineering and Biotechnology (CIGB). \\ P.O.Box 6162, 10600 Havana, Cuba \\ Fax: (53-7) 218070, (53-7) 336008 \\ E-mail: CryLab@cigb.edu.cu
}

Updated information of mechanisms for T-DNA transfer to plant cells by Agrobacterium tumefaciens is provided, focused on the role played by the different components of the virulence system. The general assessments for the establishment of efficient transformation protocols are discussed with an emphasis in the application of this methodology to monocotyledonous plants. Based on our own experience, we present the establishment of sugarcane transformation by $A$. tumefaciens as a model of application of this methodology to an important culture plant specie, previously considered recalcitrant and inaccessible for this type of genetic manipulation.

Plant transformation mediated by Agrobacterium tumefaciens, a soil plant pathogenic bacterium, has become the most used method for the introduction of foreign genes into plant cells and the subsequent regeneration of transgenic plants. A. tumefaciens naturally infects the wound sites in dicotyledonous plant causing the formation of the crown gall tumors. The first evidences indicating this bacterium as the causative agent of the crown gall goes back to more than ninety years (Smith and Townsend, 1907). Since that moment, for different reasons a large number of researches have focused on the study of this neoplastic disease and its causative pathogen. During the first and extensive period, scientific effort was devoted to disclose the mechanisms of crown gall tumor induction hoping to understand the mechanisms of oncogenesis in general, and to eventually apply this knowledge to develop drug treatments for cancer disease in animals and humans. When this hypothesis was discarded, the interest on crown gall disease largely decreased until it was evident that this tumor formation may be a result of the gene transfer from A. tumefaciens to infected plant cells.

A. tumefaciens has the exceptional ability to transfer a particular DNA segment (T-DNA) of the tumor-inducing (Ti) plasmid into the nucleus of infected cells where it is then stably integrated into the host genome and transcribed, causing the crown gall disease (Nester et al., 1984; Binns and Thomashaw, 1988). T-DNA contains two types of genes: the oncogenic genes, encoding for enzymes involved in the synthesis of auxins and cytokinins and responsible for tumor formation; and the genes encoding for the synthesis of opines. These compounds, produced by condensation between amino acids and sugars, are synthesized and excreted by the crown gall cells and consumed by $A$. tumefaciens as carbon and nitrogen sources. Outside the T-DNA are located the genes for the opine catabolism, the genes involved in the process of $\mathrm{T}$ DNA transfer from the bacterium to the plant cell and the genes involved in bacterium-bacterium plasmid conjugative transfer (Hooykaas and Schilperoort, 1992; Zupan and Zambrysky, 1995).

${ }^{1}$ Corresponding author 
Virulent strains of $A$. tumefaciens and $A$. rhizogenes, when interacting with susceptible dicotyledonous plant cells, induce diseases known as crow gall and hairy roots, respectively. These strains contain a large megaplasmid (more than $200 \mathrm{~kb}$ ) which play a key role in tumor induction and for this reason it was named Ti plasmid, or Ri in the case of $A$. rhizogenes. Ti plasmids are classified according to the opines, which are produced and excreted by the tumors they induce. During infection the T-DNA, a mobile segment of $\mathrm{Ti}$ or $\mathrm{Ri}$ plasmid, is transferred to the plant cell nucleus and integrated into the plant chromosome. The T-DNA fragment is flanked by 25-bp direct repeats, which act as a cis element signal for the transfer apparatus. The process of T-DNA transfer is mediated by the cooperative action of proteins encoded by genes determined in the Ti plasmid virulence region (vir genes) and in the bacterial chromosome. The Ti plasmid also contains the genes for opine catabolism produced by the crown gall cells, and regions for conjugative transfer and for its own integrity and stability. The $30 \mathrm{~kb}$ virulence (vir) region is a regulon organized in six operons that are essential for the T-DNA transfer (virA, virB, virD, and $\operatorname{vir} G$ ) or for the increasing of transfer efficiency (virC and virE) (Hooykaas and Schilperoort, 1992; Zupan and Zambryski, 1995, Jeon et al., 1998). Different chromosomal-determined genetic elements have shown their functional role in the attachment of $A$. tumefaciens to the plant cell and bacterial colonization: the loci $\operatorname{chvA}$ and $\operatorname{chvB}$, involved in the synthesis and excretion of the $\beta-1,2$ glucan (Cangelosi et al., 1989); the $\operatorname{chvE}$ required for the sugar enhancement of vir genes induction and bacterial chemotaxis (Ankenbauer et al., 1990, Cangelosi et al., 1990, 1991); the cel locus, responsible for the synthesis of cellulose fibrils (Matthysse 1983); the pscA (exoC) locus, playing its role in the synthesis of both cyclic glucan and acid succinoglycan (Cangelosi et at., 1987, 1991); and the att locus, which is involved in the cell surface proteins (Matthysse, 1987).

The initial results of the studies on T-DNA transfer process to plant cells demonstrate three important facts for the practical use of this process in plants transformation. Firstly, the tumor formation is a transformation process of plant cells resulted from transfer and integration of T-DNA and the subsequent expression of T-DNA genes. Secondly, the T-DNA genes are transcribed only in plant cells and do not play any role during the transfer process. Thirdly, any foreign DNA placed between the T-DNA borders can be transferred to plant cells, no matter where it comes from. These well-established facts, allowed the construction of the first vector and bacterial strain systems for plant transformation (for review Hooykaas and Schilperoort, 1992; Deblaere et al., 1985; Hamilton, 1997; Torisky et al., 1997).

The first record on transgenic tobacco plant expressing foreign genes appeared at the beginning of the last decade, although many of the molecular characteristics of this process were unknown at that moment (Herrera-Estrella, 1983). Since that crucial moment in the development of plant science, a great progress in understanding the Agrobacterium-mediated gene transfer to plant cells has been archived. However, Agrobacterium tumefaciens naturally infects only dicotyledonous plants and many economically important plants, including the cereals, remained accessible for genetic manipulation during long time. For these cases, alternative direct transformation methods have been developed (Shillito et al, 1985; Potrykus, 1991) such as polyethyleneglycol-mediated transfer (Uchimiya et al., 1986), microinjection (de la Pena et al., 1987), protoplast and intact cell electroporation (Fromm et al., 1985, 1986; Lörz et al., 1985; Arencibia 1995) and gene gun technology (Sanford, 1988). However, Agrobacterium-mediated transformation has remarkable advantages over direct transformation methods. It reduces the copy number of the transgene, potentially leading to fewer problems with transgene cosuppresion and instability (Koncz et al., 1994, Hansen et al., 1997). In addition, it is a single-cell transformation system not forming mosaic plants, which are more frequent when direct transformation is used (Enríquez-Obregón et al 1997, 1998).

Agrobacterium-mediated gene transfer into monocotyledonous plants was not possible until recently, when reproducible and efficient methodologies were established on rice (Hiei et al., 1994; Cheng et al., 1998), banana (May et al., 1995), corn (Ishida et al, 1996), wheat (Cheng et al., 1997) and sugarcane (Enríquez-Obregón 1997, 1998, Arencibia et al, 1998). Reviews on plant transformation using Agrobacterium tumefaciens and the molecular mechanisms involved have been published during the last years (Hooykaas and Schilperoort, 1992; Zupan and Zambrysky, 1995). A thorough analysis of the strategies for practical application of this methodology has been published recently (Birch, 1997).

In this work we present update information about the mechanisms of gene transfer mediated by A. tumefaciens and the assessments for application of this method in the transformation of monocotyledonous plants taking sugarcane, as a model of an important culture plant specie, not previously transformed by this method.

\section{Agrobacterium tumefaciens T-DNA transfer process}

The process of gene transfer from Agrobacterium tumefaciens to plant cells implies several essential steps: (1) bacterial colonization (2) induction of bacterial virulence system, (3) generation of T-DNA transfer complex (4) TDNA transfer and (5) integration of T-DNA into plant genome. A hypothetical model depicting the most important stages of this process is presented, supported by the most recent experimental data and accepted hypothesis on T-DNA transfer (Figure 1). 


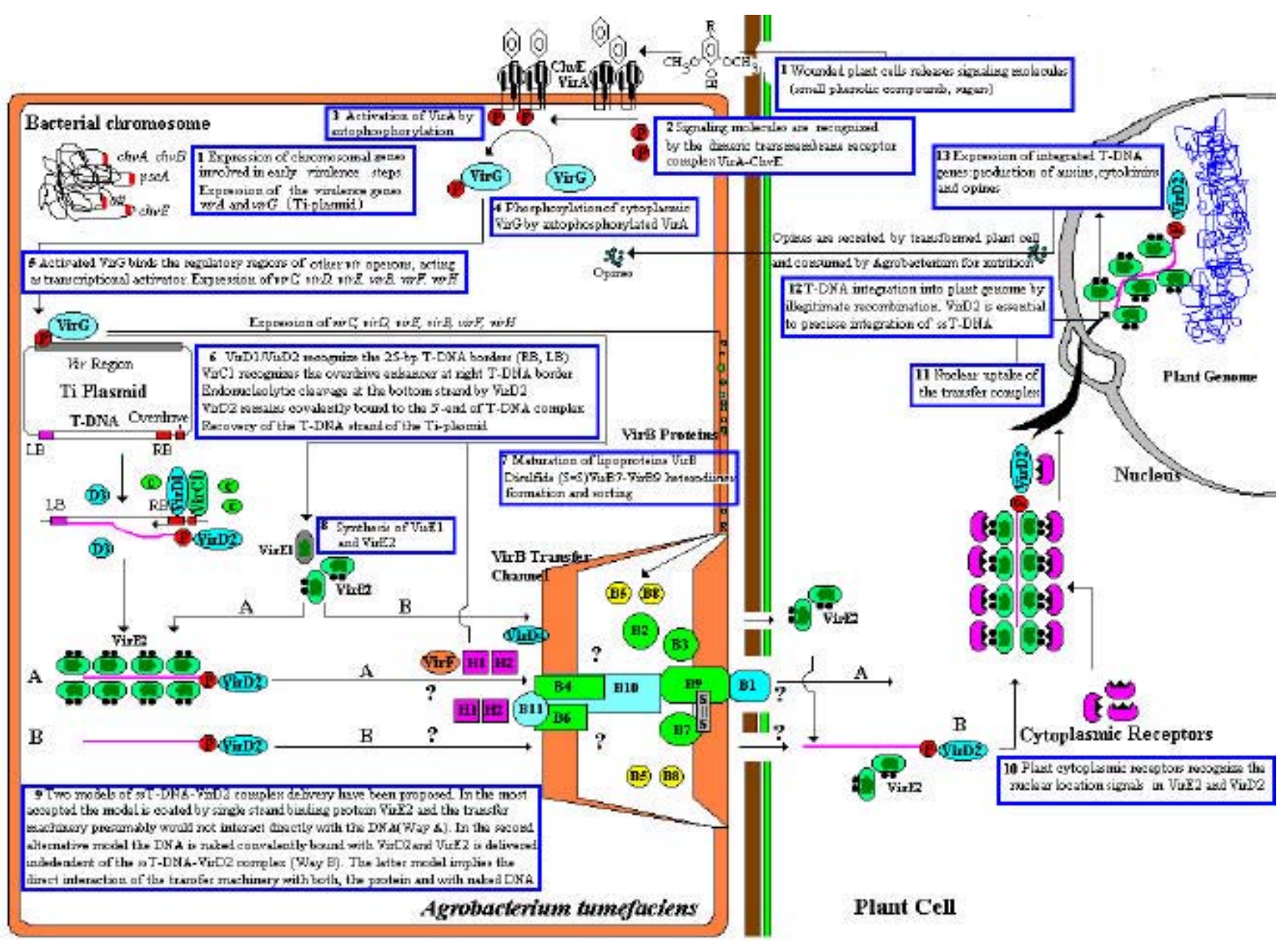

Figure 1. Basic steps in transformation of plant cells by Agrobacterium tumefaciens. The T-DNA transfer is represented according to updated knowledge on this process, although many of involved mechanisms have not been elucidated yet and the experimental results only allow hypothesize about it. Entering of T-DNA complex into the plant cell is almost completely uncharacterized and experimentally only the VirB7-VirB9 disulfide bound heterodimers have been evidenced. The most important events are briefly mentioned in chronological order (boxes 1 through 13). Each step is described in the text.

\section{Bacterial colonization}

Bacterial colonization is an essential and the earliest step in tumor induction and it takes place when A. tumefaciens is attached to the plant cell surface (Figure 2) (Matthysse , 1986). Mutagenesis studies show that non-attaching mutants loss the tumor-inducing capacity (Cangelosi et al., 1987, Douglas et al., 1982, Thomashow et al., 1987, Bradley et al., 1997). The polysaccharides of the $A$. tumefaciens cell surface are proposed to play an important role in the colonizing process. The bacterial attachment could be prevented when lipopolysaccharides (LPS) solution from virulent strains is applied to the plant tissue before interaction with virulent bacteria (Whatley and Spiess, 1977). The LPS are an integral part of the outer membrane and include the lipid A membrane anchor and the O-antigen polysaccharide in their composition. A. tumefaciens, like other plant-associative Rhizobiaceae bacteria, produces also capsular polysaccharides (Kantigens) lacking lipid anchor and having strong anionic nature and tight association with the cell. There are some evidences indicating that capsular polysaccharides may play a specific role during the interaction with the host plant. In the particular case of A. tumefaciens it was observed that the attachment of wild-type bacterium to plant cells was directly correlated with the production of an acidic polysaccharide (Bradley et al., 1997).

The chromosomal $20 \mathrm{~kb}$ att locus contains the genes required for successful bacterium attachment to the plant cell. This locus has been extensively studied using transposon insertion mutants. Insertions in the left $10 \mathrm{~kb}$ side of this region produced avirulent mutants that could 
restore its attachment capacity if the culture medium was previously conditioned by the incubation of wild-type virulent bacterium with plant cells.

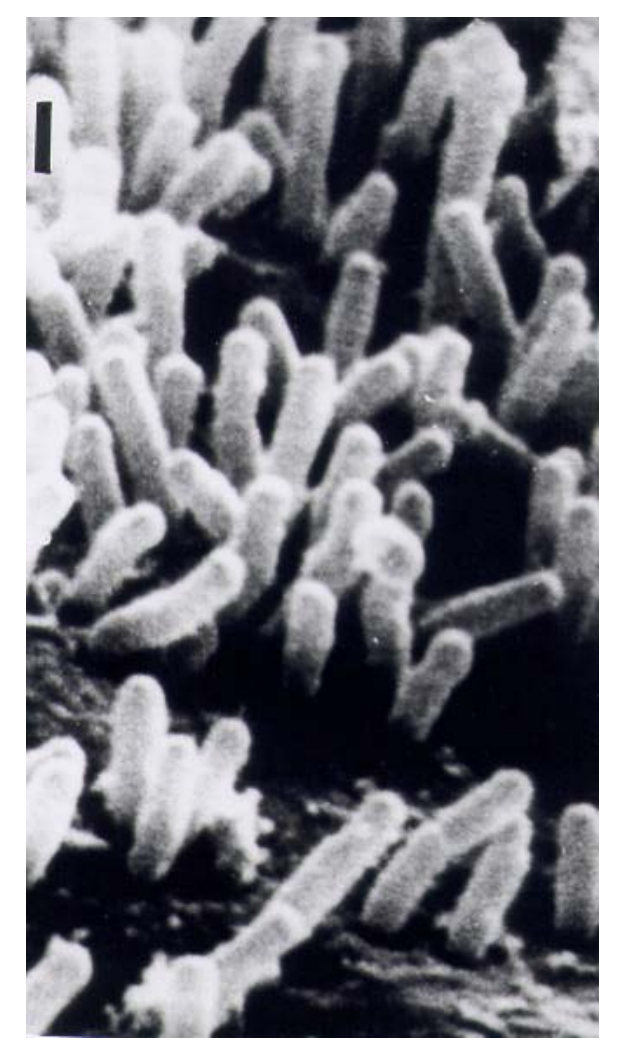

Figure 2. Agrobacterium tumefaciens colonizing tobacco leaves $(\mathrm{bar}=1 \mu \mathrm{m})$.

This previous interaction resulted in the production and accumulation of a complement, absent in the mutant strain, conditioning the medium and allowing the attachment to the plant cell. In contrast, mutational insertion in the $10 \mathrm{~kb}$ right side of the att locus resulted in the irreversible loss of attachment capacity, which could not be restored by conditioned medium (Bradley, 1997). These results suggest that genes, placed at att left side, are involved in molecular signaling events, while the right side genes are likely to be responsible for the synthesis of fundamental components. The att left side suggests an operon composed by nine open reading frames (ORF). Four of these ORF show homology to the genes involved in the so-called periplasmic binding protein dependent (or ABC) transport system (Ames et al., 1990; Higgings et al., 1990). The mutant analysis evidenced a failure in the production and accumulation of specific compounds essential for bacterial attachment. The ABC transporter encoding genes may be involved in the secretion of this substances or in the introduction into bacteria of some plant-originated activators of the synthesis of that compound specific for attachment (Matthysse et al. 1996).

\section{Induction of bacterial virulence system}

The T-DNA transfer is mediated by products encoded by the 30-40 kb vir region of the Ti plasmid. This region is composed by at least six essential operons (vir A, vir B, vir $C$, vir $D$, vir $E$, virG ) and two non-essential (virF, virH). The number of genes per operon differs, virA, virG and $\operatorname{vir} F$ have only one gene; $\operatorname{virE}, \operatorname{vir} C$, virH have two genes while virD and virB have four and eleven genes respectively. The only constitutive operons are virA and virG, coding for a two-component (VirA-VirG) system activating the transcription of the other vir genes. The VirA-VirG two-component system has structural and functional similarities to other already described for other cellular mechanisms (Nixon, 1986, Iuchi, 1993).

VirA is a transmembrane dimeric sensor protein that detects signal molecules, mainly small phenolic compounds, released from wounded plants (Pan et al., 1993). The signals for VirA activation include acidic $\mathrm{pH}$, phenolic compounds, such as acetosyringone (Winans et al., 1992), and certain class of monosaccharides which acts sinergistically with phenolic compounds (Ankenbauer et al., 1990; Cangelosi et al., 1990; Shimoda et al., 1990; Doty et al., 1996). VirA protein can be structurally defined into three domains: the periplasmic or input domain and two transmembrane domains (TM1 and TM2). The TM1 and TM2 domains act as a transmitter (signaling) and receiver (sensor) (Parkinson, 1993). The periplasmic domain is important for monosaccharide detection (Chang and Winans, 1992). Within the periplasmic domain, adjacent to the TM2 domain is an amphipatic helix, with strong hydrophilic and hydrophobic regions (Heath et al., 1995). This structure is characteristic for other transmembrane sensor proteins and folds the protein to be simultaneously aligned with the inner membrane and anchored in the membrane (Seligman and Manoil, 1994). The TM2 is the kinase domain and plays a crucial role in the activation of VirA, phosphorylating itself on a conserved His-474 residue (Huang et al., 1990; Jin et al. 1990a $1990 \mathrm{~b}$ ) in response to signaling molecules from wounded plant sites. Monosaccharide detection by VirA is an important amplification system and responds to low levels of phenolic compounds. The induction of this system is only possible through the periplasmic sugar (glucose/galactose) binding protein ChvE (Ankenbauer and Nester, 1990; Cangelosi et al., 1990), which interacts with VirA (Shimoda et al., 1990, 1993; Turk et al., 1993; Chang and Winans, 1992). Recent studies for determination of VirA regions, important for its sensing activity suggested the position, which may be involved on TM1-TM2 interaction. This interaction causes the exposure of the amphipathic helix to small phenolic compounds and suggests a putative model for the VirAChvE interaction (Doty et al., 1996).

Activated VirA has the capacity to transfer its phosphate to a conserved aspartate residue of the cytoplasmic DNA binding protein VirG (Jin et al. 1990a, 1990b; Pan et al., 1993). VirG functions as a transcriptional factor regulating the expression of vir genes when it is phosphorilated by VirA (Jin et al., 1990a, 1990b). The C-terminal region is 
responsible for the DNA binding activity, while the Nterminal is the phosphorylation domain and shows homology with the VirA receiver (sensor) domain.

The activation of vir system also depends on external factors like temperature and $\mathrm{pH}$. At temperatures greater than $32^{\circ} \mathrm{C}$, the vir genes are not expressed because of a conformational change in the folding of VirA induce the inactivation of its properties. (Jin et al., 1993). The effect of temperature on VirA is suppressed by a mutant form of $\operatorname{VirG}\left(\operatorname{VirG}^{\mathrm{c}}\right)$, which activates the constitutive expression of the vir genes. Hovewer, this mutant cannot confers the virulence capacity at that temperature to Agrobacterium, probably because the folding of other proteins that actively participate in the T-DNA transfer process are also affected at high temperature (Fullner and Nester, 1996).

\section{Generation of T-DNA transfer complex}

The activation of vir genes produces the generation of single-stranded (ss) molecules representing the copy of the bottom T-DNA strand. Any DNA placed between T-DNA borders will be transferred to the plant cell as single strand DNA and integrated into the plant genome. These are the only cis acting elements of the T-DNA transfer system. The proteins VirD1 and VirD2 play a key role in this step, recognizing the T-DNA border sequences and nicking (endonuclease activity) the bottom strand at each border. The nick sites are assumed as the initiation and termination sites for T-strand recovery. After endonucleotidic cleavage, VirD2 remains covalently attached to the 5'-end of the ssT-strand. This association prevents the exonucleolytic attack to the 5'-end of the ss-T-strand (Dürrenberger et al., 1989) and distinguishes the 5'-end as the leading end of the T-DNA transfer complex. VirD1 interacts with the region where the ss-T-strand is originated. Experiments in vitro evidenced that the presence of VirD1 is essential for the cleavage of supercoiled stranded substrate by VirD2 (Zupan and Zambryski, 1995; Christie et al., 1997). The simultaneous restoration of the excised ss-T-strand is evolutionarily related to other bacterial conjugative DNA transfer processes, which includes the generation of the single strand DNA (Zupan and Zambryski, 1995; Christie et al., 1997; Lessl et al., 1994).

Extensive mutation or deletion of the right T-DNA border is followed by almost complete loss of T-DNA transfer capacity, while at the left border results in lower transfer efficiency (Hille et al., 1983). This fact indicates that Tstrand synthesis is initiated at the right border, it proceeds in the 5' to 3' direction and the termination process takes place even when the left border is mutated or completely absent, although with lower efficiency. Left border may act as a starting site for ssT-strand synthesis but the efficiency is much lower (Filichkin and Gelvin, 1993). The difference may be a consequence of the presence of an enhancer or "overdrive" sequence next to the right border (Peralta and Ream, 1985). This enhancer has been found to be specifically recognized by VirC1 protein (Toro et al.,
1989). Deletion of virC operon is followed by attenuation of virulence of the Agrobacterium strains (van Haaren at al., 1987; Rogowsky et al., 1990).

\section{The T-DNA transfer. Two models for the translocation of T-DNA-complex}

The transferring vehicle to the plant nucleus is a ssT-DNAprotein complex. Is must be translocated to the plant nucleus passing through three membranes, the plant cell wall and cellular spaces. According to the most accepted model, the ssT-DNA-VirD2 complex is coated by the 69 $\mathrm{kDa}$ VirE2 protein, a single strand DNA binding protein. This cooperative association prevents the attack of nucleases and, in addition, extends the ssT-DNA strand reducing the complex diameter to approximately $2 \mathrm{~nm}$, making the translocation through membrane channels easier. However, that association does not stabilize T-DNA complex inside Agrobacterium (Zupan et al., 1996). VirE2 contains two plant nuclear location signals (NLS) and VirD2 one (Bravo Angel et al, 1998). This fact indicates that both proteins presumably play important roles, once the complex is in the plant cell mediating the complex uptake to the nucleus (Herrera-Estrella et al., 1990; Shurvinton et al., 1992; Rossi et al., 1993, Tinland et al., 1995, Zupan et al., 1996). The deletion of NLS in one of these proteins reduces, but does not totally inhibit, the ssT-DNA transfer and its integration into plant genome, evidencing that the other partner can, at least partially, assume the function of the absent protein.

It is known that VirE1 is essential for the export of VirE2 to the plant cell, although other specific functions are still uncharacterized (Binns et al., 1995). Bacterial strains mutated in virE1, cannot export VirE2 which is accumulated inside the bacterium. Such mutants can be complemented if coinfected with a strain that can export VirE2, indicating that this protein can be exported independently and that the transfer of VirE2 as part of the ss-T-DNA complex is not necessary for the transmission event (Sundberg et al., 1996) being possible to transfer naked T-DNA to the plant cell (Binns et al., 1995; Sundberg et al., 1996).

From these experimental evidences, an alternative model was brought to light for ssT-DNA complex transfer. This model proposes that the transfer complex is a single-strand DNA covalently bound at its 5'-end with VirD2, but uncoated by VirE2. The independent export of VirE2 to plant cell is presented as a natural process, and once the naked ssT-DNA-VirD2 complex is inside the plant cell, it is coated by VirE2 (Binns et al., 1995; Lessl et al., 1994). It is also possible that the process can be performed by one of the proposed alternatives according to the infection conditions.

Previous researches described the role of $9.5 \mathrm{~kb}$ virB operon in the generation of a suitable cell surface structure for the ssT-DNA complex transfer from bacterium to plant 
(Finberg et al., 1995; Stephens et al., 1995; Zhou and Christie, 1997; Dang and Christie, 1997; Rashkova et al., 1997, Fernandez et al., 1996; Beaupré et al., 1997). The VirD4 protein is also required for the ss-T-DNA transport. The function of VirD4 is the ATP-dependent linkage of protein complex necessary for T-DNA translocation (Firth et al., 1996).

VirB are proteins that present hydrophathy characteristics similar to other membrane-associated proteins (Kuldau et al., 1990; Shirasu et al., 1990, 1994; Thompson et al., 1988; Ward et al., 1988). VirD4 is a transmembrane protein but predominantly located at the cytoplasmatic side of the cytoplasmic membrane (Okamoto et al., 1991). Comparative studies showed a high degree of homology between the virB operon and transfer regions of broad host range (BHR) plasmids in genetic organization, nucleotide sequence and protein function (Pohlman et al., 1994; Lessl et al., 1992). Both systems deliver non-self transmissible DNA-protein complex to recipient host cell. In addition, they have the capacity to DNA interkingdom delivery (Heinemann and Sprague, 1989; Bundock et al., 1995; Piers et al., 1996) suggesting that the T-DNA transfer apparatus and conjugation systems are related and probably evolved from a common ancestral (Christie et al., 1997; Oger et al., 1998).

The majority of VirB proteins are assembled as a membrane-spanning protein channel involving both membranes (Shirasu and Kado, 1993a, 1993b; Shirasu et al., 1994; Stephens et al., 1995; Das and Xie, 1998). Except for VirB11, they have multiple periplasmic domains (Christie, 1997). VirB1 is the only member of VirB proteins found in the extracellular milieu (Baron et al., 1997), although it is possible that some of the other VirB proteins may be redistributed during the process of biogenesis and functioning of the transcellular conjugal channel (Christie, 1997). That could be the case for the VirB2, a protein with deduced extracellular functions. Vir B2 is translated as a 12 $\mathrm{kDa}$ proprotein, which is later processed by proteolysis to its mature $7 \mathrm{kDa}$ functional form (Jones et al., 1996).

VirB4 and VirB11 are hydrophilic ATPases necessary for active DNA transfer. Vir B11 lacks a continuous sequence of hydrophobic residues, forming periplasmic domains. Despite these structural characteristics, less than one third of VirB11 constitutes its soluble fraction, while the rest of the protein remains associated with the cytoplasmic membrane (Rashkova et al., 1997). These characteristics are atypical for this type of protein and evidence the possible dynamic co-existence of different conformational forms in vivo. VirB4 tightly associates with the cytoplasmic membrane (Dang and Christie, 1997). It contains two putative extracellular domains conferring transmembrane topology to this protein, which presumably allows the ATPdependent conformational change in the conjugation channel. Probably, the functional forms of VirB4 and VirB11 are homo and heterodimers (Dang and Christie, 1997). The VirB4 synthesis is well correlated with the accumulation and distribution of VirB3. Other protein, VirB7, seems to be crucial for the conformation of the transfer apparatus. VirB7 interacts with VirB9 forming heterodimers and probably higher-order multimeric complexes. The synthesis of VirB9 and its stable accumulation depends of heterodimer conformation, indicating that VirB9 alone may be unstable and requires the association with VirB7 (Anderson et al., 1996). In this intermolecular monomeric subunits are joined by disulfide bridges. The VirB7-VirB9 heterodimer is assumed to stabilize other Vir proteins during assembly of functional transmembrane channels (Fernandez et al., 1996; Spudich et al., 1996).

Some of the initial steps of biogenesis of ssT-DNA complex apparatus have been recently identified. Firstly, VirB7 and VirB9 monomers are exported to the membrane and processed. They interact each other to form covalently cross-linked homo and heterodimers. Although the role of both types of dimers in the biogenesis of the transfer apparatus is widely accepted, it is likely that only heterodimers are essential (Fernández et al., 1996; Spudich et al., 1996). Subsequently, the VirB7-VirB9 heterodimer is sorted to the outer membrane. The sorting mechanism has not been elucidated (Christie, 1997). The next step implies the interaction with the other Vir proteins for assembling the transfer channel with the contribution of the transglycosidase VirB1

It is known that VirB2 through VirB11 are essential for DNA transfer, suggesting that these proteins are fundamental component of the transfer apparatus (Berger and Christie, 1993, 1994) while VirB1 has a lesser contribution to this process.

Two accessory vir operons, present in the octopine Tiplasmid, are virF and virH. The virF operon encodes for a $23 \mathrm{kDa}$ protein that functions once the T-DNA complex is inside the plant cells via the conjugal channel or independently, as it was assumed for VirE2 export. The role of VirF seems to be related with the nuclear targeting of the ssT-DNA complex but its contribution is less important than in the case of VirF (Hooykass and Schilperoort, 1992). The virH operon consists of two genes that code for VirH1 and VirH2 proteins. These Vir proteins are not essential but could enhance the transfer efficiency, detoxifying certain plant compounds that can affect bacterial growth (Kanemoto et al., 1989). If this is the function of VirH proteins, they play a role in the host range specificity of bacterial strain for different plant species.

\section{Integration of T-DNA into plant genome}

Inside the plant cell, the ssT-DNA complex is targeted to the nucleus crossing the nuclear membrane. Two Vir proteins have been found to be important in this step: VirD2 and VirE2, which are the most important, and probably VirF, which has a minor contribution to this process (Hooykaas and Schilperoort, 1992). The nuclear 
location signals (NLS) of VirD2 and VirE2 play an important role in nuclear targeting of the delivered ss-TDNA complex, as early described. VirD2 has one functional NLS. The ssT-DNA complex is a large (up to 20 $\mathrm{kb}$ ) nucleoprotein complex containing only one 5'end covalently attached VirD2 protein per complex. But the complex is coated by a large number of VirE2 molecules (approximately 600 per a $20 \mathrm{~kb}$ T-DNA), and each of them has two NLS. The two NLS of VirE2 have been considered important for the continuos nuclear import of ss-T-DNA complex, probably by keeping both sides of nuclear pores simultaneously open. The nuclear import is probably mediated also by specific NLS-binding proteins, which are present in plant cytoplasm.

The final step of T-DNA transfer is its integration into the plant genome. The mechanism involved in the T-DNA integration has not been characterized. It is considered that the integration occurs by illegitimate recombination (Gheysen et al., 1991, Lehman et al., 1994; Puchta, 1998). According to this model, paring of a few bases, known as micro-homologies, are required for a pre-annealing step between T-DNA strand coupled with VirD2 and plant DNA. These homologies are very low and provide just a minimum specificity for the recombination process by positioning VirD2 for the ligation. The $3^{\prime}$-end or adjacent sequences of T-DNA find some low homologies with plant DNA resulting in the first contact (synapses) between the T-strand and plant DNA and forming a gap in 3'-5' strand of plant DNA. Displaced plant DNA is subsequently cut at the 3'-end position of the gap by endonucleases, and the first nucleotide of the 5' attaches to VirD2 pairs with a nucleotide in the top $\left(5^{\prime}-3^{\prime}\right)$ plant DNA strand. The 3' overhanging part of T-DNA together with displaced plant DNA are digested away, either by endonucleases or by 3'5' exonucleases. Then, the 5' attached to VirD2 end and other 3'-end of T-strand (paired with plant DNA during since the first step of integration process) joins the nicks in the bottom plant DNA strand. Once the introduction of Tstrand in the 3'-5' strand of the plant DNA is completed, a torsion followed by a nick into the opposite plant DNA strand is produced. This situation activates the repair mechanism of the plant cell and the complementary strand is synthesized using the early inserted T-DNA strand as a template (Tinland et al., 1995).

VirD2 has an active role in the precise integration on $\mathrm{T}$ strand in the plant chromosome. The release of VirD2 protein may provide the energy containing in its phosphodiester bond, at the Tyr29 residue, with the first nucleotide of T-strand providing the 5'-end of the T-strand for ligation to the plant DNA. This phosphodiester bond can serve as electrophilic substrate for nucleophilic 3'-OH from nicked plant DNA (Jayaram, 1994). When the mutant VirD2 protein is transferred attached to the T-strand, the integration process take place with the loss of nucleotides at the 5'-end of the T-strand (Tinland et al., 1995).

\section{Agrobacterium-mediated transformation in monocotyledonous plants.}

Transformation is currently used for genetic manipulation of more than 120 species of at least 35 families, including the major economic crops, vegetables, ornamental, medicinal, fruit, tree and pasture plants (Birch, 1997), using Agrobacterium-mediated or direct transformation methods. The idea that some species cannot accept the integration of foreign DNA in its genome and lack the capacity to be transformed is unacceptable under the increasing number of species that have been transformed.

However, efficient methodologies of Agrobacteriummediated gene transfer have been established mainly for dicotyledoneous plants (Figure 3). These plants have been considered to be outside the Agrobacterium host range and other gene-transfer methods were developed for them. To develop these methodologies for a monocotyledoneous plant it is important to take into consideration the critical aspects in the Agrobacterium tumefaciens-plant interaction, the cellular and tissue culture methodologies developed for that species. The suitable genetic materials (bacterial strains, binary vectors, reporter and marker genes, promoters) and molecular biology techniques available in the laboratory are necessary for selection of the DNA to be introduced. This DNA must be able to be expressed in plants making possible the identification of transformed plants in selectable medium and using molecular biology techniques to test and characterize the transformation events (for review Birch, 1997).

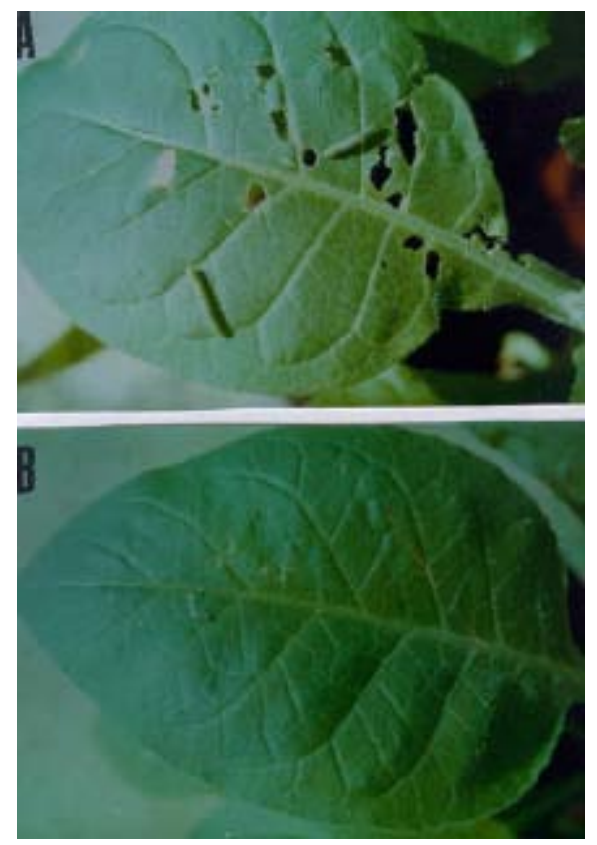

Figure 3. Agrobacterium-mediated transformation was firstly established for dicotyledonous plants and subsequently used for introduction of genes conferring new attributes to transgenic plants. Among those applications, the obtainment of transgenic plants resistant to insect attack 
has become one of the most important targets for plant genetic engineering. Transgenic tobacco plants expressing Bacillus thuringiensis $\delta$-endotoxin gene cry1Ab (B) successfully resists the attack of Heliothis virescens larvae. Non-transgenic plant (A) exhibits the damages of pest attack.

The optimization of Agrobacterium tumefaciens-plant interaction is probably the most important aspect to be considered. It includes the integrity of the bacterial strain, its correct manipulation and the study of reaction in wounded plant tissue, which may develop in a necrotic process in the wounded tissue or affect the interaction and release of inducers or repressors of Agrobacterium virulence system. The type of explant is also an important fact and it must be suitable for regeneration allowing the recovery of whole transgenic plants. The establishment of a method for the efficient regeneration of one particular species is crucial for its transformation.

It is recommended to work firstly on the establishment of the optimal conditions for gene transfer through preliminary experiments of transient gene expression using reporter genes (Jefferson et al., 1987). This opinion is supported by the fact that Agrobacterium-mediated gene transfer is a complex process and many aspects of the mechanisms involved remain unknown. The transient expression experiments help to identify also the explants, which may be used as targets for gene transfer, providing evidence of successful transformation events and correct expression of transgene.

The preliminary studies also include the use of histologically defined tissues of different explants and regeneration of the whole plant . Transient expression experiments may be directed to the regenerable tissue and cell. Optimization of transient activity is a waste of time if experiments are conducted on non-regenerable tissues or consider conditions inhibiting regeneration or altering the molecular integrity of the transformed cell. Agrobacteriummediated transfer introduce a small number of copies of foreign DNA per cell compared with particle bombardment or electroporation, but high efficiencies of stable transformants may be obtained even from cells without positive results in transient expression assays.

These aspects are important to establish a transformation procedure for any plant, especially for those species categorized as recalcitrant. Cereals, legumes and woody plants, which are very difficult to transform or remain untransformed, can be included in this category. Many species, originally considered in this category, has been transformed in recent years. One of these species, sugarcane, has been transformed in our laboratory.

\section{Agrobacterium-mediated transformation sugarcane (Saccharum oficinarum L.)}

Sugarcane (Saccharum officinarum L.) is cultivated on large scale in tropical and subtropical regions as raw material for sugar and industrial products, such as furfural, dextrans, and alcohol (Martín et al., 1982). Sugarcane represents $65 \%$ of the world sugar production (AgraEurope 1995). Some natural pharmaceutical compounds are derived from sugarcane (Menéndez et al. 1994); additionally, agricultural and industrial by-products of the sugar production process are extensively employed for animal nutrition, food processing, paper manufacturing and fuel (Patrau 1989). Traditional plant breeding techniques, together with classic biotechnological approaches, have been extensively used to increase crop yields by selecting improved varieties which are more productive and resistant to diseases and pathogens. Unfortunately, some important traits such as resistance to insect pests and to some herbicides, appear to be absent from the genetic pools of sugarcane cultivars (Arencibia et al. 1997). The use of plant transformation methods to introduce resistance genes into plant genomes may have an important impact on sugarcane yields. Recently, our group published a report evidencing the generation of the first transgenic sugarcane lines resistant to stem-borer attack (Arencibia et al. 1997).

The lack of a reproducible methodology for stable transformation of sugarcane was an important obstacle for its genetic manipulation during many years. In 1992, Bower and Birch successfully recovered transgenic sugarcane plants from cell suspensions and embryogenic calli transformed by particle bombardment (Bower and Birch, 1992). Simultaneously, Arencibia et al. (1992) developed a procedure for stable transformation of sugarcane by electroporation of meristematic tissue. Later, a method to produce transgenic sugarcane plants by intact cell electroporation was established by the same group (Arencibia et al. 1995). The development of herbicideresistant plants containing the bar gene and derived from the commercial variety NCo 310 by biolistic transformation (Gallo-Meagher and Irvine 1996) has been recently reported. However, direct plant-transformation systems are known to be traumatic to the cells, expensive due to the need of special equipment, and poorly reproducible because of the variable transgene copy-number per genome.

\section{Establishment of transformation protocol}

Optimization of the Agrobacterium-mediated DNA transfer to sugarcane meristems has recently been reported (Enríquez-Obregón et al. 1997,1998). We hypothesize that the problems of transferring Agrobacterium-mediated genes to plants are related with the poor survival rate of the target cells. We attempted toovercome necrosis by using a set of antioxidant compounds, allowing cell survival and the development of competence to gene transfer.

The design of an adequate artificial environment to favor the interaction of $A$. tumefaciens with the plant tissue is critical for the success of genetic transformation experiments. Oxidative burst, phenolization and the 
subsequent cell death have been described as frequent phenomena during the interaction of A. tumefaciens with monocotyledonous plant cells. We treated the explants with a set of antinecrotic compounds in order to minimize the Agrobacterium-induced hypersensitive response. In a previous report (Enríquez-Obregón et al., 1997) we showed that the coculture of explants with A. tumefaciens induces rapid necrosis in the tissue. We tested several antinecrotic treatments on the Agrobacterium-mediated DNA transfer and callus formation, demonstrating that geneticallytransformed calli could be obtained only when a mix of antinecrotic compounds with remarkable antioxidative activity was added. Thus, this may be a reliable approach to overcome the Agrobacterium-induced hypersensitive cell death. As the physiological role of each compound during plant-microbial interaction has not been established already, we prefer to use the term "antinecrotic compounds" instead of "antioxidant compounds". The application of such compounds in a method for Agrobacterium-mediated transformation of grape was recently published by Perl et al. (1996); however, we do not know of any report on stable genetic transformation of monocotyledonous plants using antinecrotic treatments.

It was reported that the enrichment of the media with sugars and a low $\mathrm{pH}$ were both important factors in achieving efficient transformation of rice and maize by A. tumefaciens (Hiei et al., 1994; Ishida et al., 1996). We performed the infection step in a medium supplemented with glucose and sucrose at the concentrations suggested in the literature, but the observed transformation efficiencies were lower than those obtained when the pre-coculture was performed in conventional low-sugar medium (Enríquez-Obregón et al., 1997). Good transformation efficiencies were obtained without infecting the explants in low-pH media. We assume that osmotic conditions affect the process of recognition of plant cells by the Agrobacterium. These results are in agreement with those reported by Rashid et al. (1996), who stated that neither high sugar concentrations nor low $\mathrm{pH}$ are required in the genetic transformation process.

Recent works on Agrobacterium-mediated genetic transformation of monocotyledonous plant species are focused on the use of the so-called "super-binary" vector systems, i.e. binary vectors carrying a DNA fragment from the A. tumefaciens virulence region (Torisky et al., 1997). Our procedures, however, are based on conventional genetic vectors; in addition, acetosyringone - a commonly used inductor of A. tumefaciens vir genes (Rashid et al. 1996) - is not required during infection. We conclude that in our system the vir genes naturally carried by $A$. tumefaciens PGV2260 are sufficient to initiate the infection and transformation processes; their induction occurs normally without adding chemical activators. In this study we investigated the regeneration abilities of the obtained calli (Deblaere et al., 1985). The results were similar to those observed under normal conditions and were not affected by the duration of the antinecrotic treatment. We obtained a classical insertion pattern usually observed in $A$. tumefaciens-transformed plants without any discernible genetic rearrangement. The number of independent insertion patterns per individual plant genome was one or two. The results are in good agreement with those reported for other systems of Agrobacterium-mediated transformation; they also contrast with the complex multicopy insertion patterns described for the "first-generation" transgenic sugarcane plants produced by intact-cell electroporation (Arencibia et al., 1995). The latter phenomena are clearly undesirable due to the lack of control, the possibility of gene silencing, cosuppression, etc.

By using the developed procedure (Figures 4 and 5), we are currently developing transgenic sugarcane lines carrying genes for resistance to insects and fungal diseases.

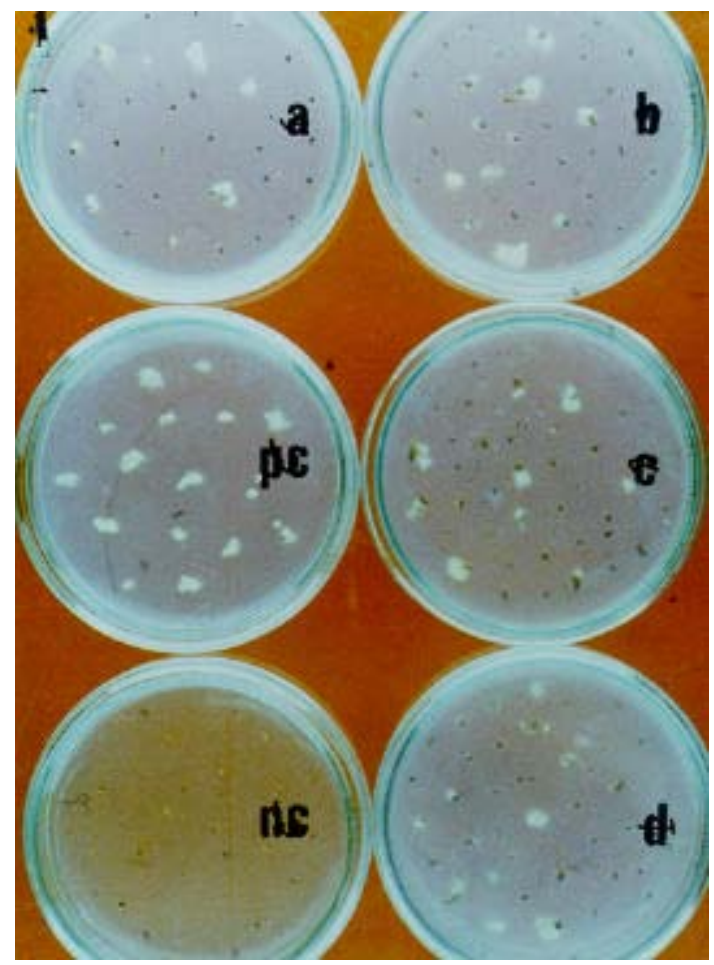

Figure 4. Sugarcane transformation by Agrobacterium tumefaciens. Selection of PTT-resistant calli on selective medium, supplemented with $4 \mathrm{mg} / \mathrm{L}$ of PPT. The nontransformed calli turned brown and died (plate nc) while the transformed calli (plates a-d) resist the preasure selection and grow healtly. $(\mathrm{pc})$ : regeneration control of non-selective medium.

\section{Concluding Remarks}

Agrobacterium tumefaciens is more than the causative agent of crown gall disease affecting dicotyledonous plants. It is also the natural instance for the introduction of foreign genes in plants allowing its genetic manipulation. Similarities have been found between T-DNA and conjugal transfer systems. They are evolutionary related and apparently evolved from a common ancestor. 
Although the gene transfer mechanisms remain largely unknown, great progress has been obtained in the implementation of transformation protocols for both dicotyledonous and monocotyledonous plants. Particularly important is the extension of this single-cell transformation methodology to monocotyledonous plants. This advance has biological and practical implications. Firstly, because of the advantages of $A$. tumefaciens-mediated gene transfer over the direct transformation methods, which where the only way for genetic manipulation of economically important crops as cereals and legumes. Secondly, it has been demonstrated that T-DNA is transferred to dicotyledonous and monocotyledonous plants by an identical molecular mechanism. This confirmation implies that any plant can potentially be transformed by this method if a suitable transformation protocol is established.

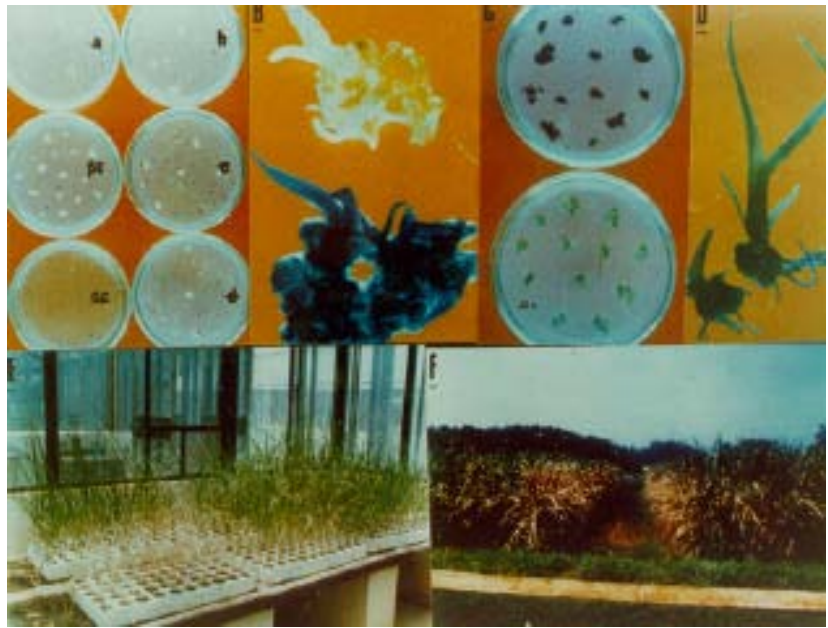

Figure 5. Sugarcane transformation by Agrobacterium tumefaciens. A-F. (A) Selection of PTT-resistant calli on selective medium, supplemented with $4 \mathrm{mg} / \mathrm{L}$ of PPT. (B) Histochemical GUS-activity assay in a shoot-developing PPT resistant callus transformed by A. tumefaciens bearing the pGT GUSBAR plasmid; in the top, non-transformed shoot-developing callus. (C) Regeneration of transformants from PPT-resistant calli on selective medium, supplemented with $4 \mathrm{mg} / \mathrm{L}$ of PPT (bottom), compared with necrosed non-transformed calli on the same medium (top). (D) Whole plant GUS expression assay in two transformed individuals (after regeneration). (E) Sugarcane plants under greenhouse conditions two weeks after the application of the herbicide. Plants were sprayed with BASTA at $2.5 \mathrm{~g} / \mathrm{L}$; non-transgenic plants turned brown and died. (F) Sugarcane plants under field conditions, The lanes between the field way are not transformed and died after application of the herbicide.

The Agrobacterium-mediated transformation protocols differ from one plant species to other and, within species, from one cultivar to other. In consequence, the optimization of Agrobacterium-mediated transformation methodologies requires the consideration of several factors that can be determined in the successful transformation of one species. Firstly, the optimization of Agrobacterium-plant interaction on competent cells from different regenerable tissues. Secondly, the development of a suitable method for regeneration from transformed cells.

We have presented the case of sugarcane, previously inaccessible for genetic manipulation, as a model of successful establishment of a routine protocol for Agrobacterium-mediated transformation. In this case, we have optimized the interaction with Agrobacterium by using antinecrotic compounds preventing the development of necrosis in wounded plant cells. The plant meristem was the explant selected for transformation for its efficient regeneration capacity that allowed the production of whole transgenic lines.

Undoubtedly, the development of transformation procedures based on A. tumefaciens-mediated gene transfer for new economically important species are advisable and the results obtained in recent years evidence a promising future.

\section{References}

Agra-Europe (1995). Cane taking larger share of world sugar output. Sugar cane expected to be main supply of world sugar production in 1994/5. Agra-Europe. January 20, p M7.

Ames, G. F.L., Mimura, C.S. and Shyamala, V. (1990). Bacterial periplasmic permeases belong to a family of transport proteins operating from Escherichia coli to human: traffic ATPases. FEMs Microbiological Review 75:429-446.

Anderson, L.B., Hertzel, A.V. and Das. A. (1996). Agrobacterium tumefaciens VirB7 and VirB9 form a disulfide -linked protein complex. Proceedings of the National Academy of Sciences USA 93:8889-8894.

Ankenbauer, RG and EW Nester (1990). Sugar-mediated induction of Agrobacterium tumefaciens virulence genes: structural specificity and activities of monosaccharides. Journal of Bacteriology 172: 6442-6446.

Arencibia, A.D., Carmona, E.R., Tellez, P., Chan, M.T. Yu, S.M., Trujillo, L.E. and Oramas, P. (1998). An efficient protocol for sugarcane (Saccharum spp. L.) transformation mediated by Agrobacterium tumefaciens. Transgenic Research 7:1-10.

Arencibia, A., Vázquez, R., Prieto, D., Téllez, P., Carmona, E., Coego, A., Hernández, L., de la Riva, G. and Selman-Housein, G. (1997). Transgenic sugarcane plants resistant to stem-borer attack. Molecular Breeding 3:247255. 
Arencibia, A., Molina, P., Gutierrez, C., Fuentes,A., Greenidge, V., Menendez, E, de la Riva, G. and SelmanHousein, G. (1992). Regeneration of transgenic sugarcane (Saccharum officinarum L.) plants from intact meristematic tissue transformed by electroporation. Biotecnología Aplicada 9:156-165

Arencibia, A., Molina, P. de la Riva, G. and SelmanHousein, G. (1995). Production of transgenic sugarcane (Saccharum officinarum L.) plants by intact cell electroporation. Plant Cell Reports 14:305-309

Baron, C., Llosa, M., Zhou, S. and Zambryski, P.C. (1997). VirB1, a component of the T-complex transfer machinery of Agrobacterium tumefaciens is processed to a C-terminal secreted product VirB1*. Journal of Bacteriology 179:1203-1210.

Beaupre, C.E., Bohne, J., Dale, E.M. and Binns, A.N. (1997). Interactions between VirB9 and VirB10 proteins involved in the movement of DNA from Agrobacterium tumefaciens into plant cells. Journal of Bacteriology 179:78-89.

Berger, B.R. and Christie, P.J. (1993). The Agrobacterium tumefaciens virB4 gene product is an essential virulence protein requiring an intact nucleoside triphosphate-binding domain. Journal of Bacteriology 175:1723-1734.

Berger, B.R. and Christie, P.J. (1994). Genetic complementation analysis of the Agrobacterium tumefaciens virB operon: virB2 through virB11 are essential virulence genes. Journal of Bacteriology 176: 3646-3660.

Binns, A.N. and Thomashow, M.F. (1988). Cell biology of Agrobacterium infection and transformation of plants. Annual Review of Microbiology 42: 575-606.

Binns, A.N., Beaupre, C.E. and Dale, M. (1995). Inhibition of VirB-mediated transfer of diverse substrate from Agrobacterium tumefaciens by the IncQ plasmid RSF1010. Journal of Bacteriology 177:4890-4899.

Birch, R.G. (1997). Plant transformation: Problems and strategies for practical application. Annual Review of Plant Physiology and Plant Molecular Biology 48:297-326.

Bower, R. and Birch, R..G. (1992).Transgenic sugarcane plants via microproyectile bombardment. The Plant Journal 2:409-416.

Bradley L.R., Kim, J.S. and Matthysse, A.G. (1997). Attachment of Agrobacterium tumefaciens to Carrot Cells and Arabidopsis wound sites is correlated with the presence of a cell-associated, acidic polysaccharide. Journal of Bacteriology 179:5372-5379.

Bravo Angel, A.M., Hohn, B. and Tinland, B. (1998). The omega sequence of VirD2 is important but not essential for efficient transfer of the T-DNA by Agrobacterium tumefaciens. Molecular Plant-Microbe Interactions 11:5763.

Bundock, P. A., den Dulk-Ras, A., Beijerbergen, A. and PJJ Hooykaas (1995). Trans-kingdon T-DNA transfer from Agrobacterium tumefaciens to Saccharomyces cerevisiae. EMBO Journal 14:3206-3214.

Cangelosi, G.A., Hung, L., Puvanesarajah, V., Stacey, G., Ozga. D.A., Leigh, J.A. and Nester, E.W. (1987). Common loci for Agrobacterium tumefaciens and Rhizobium meliloti exopolysaccharide synthesis and their role in plant interaction. Journal of Bacteriology 169:2086-2091.

Cangelosi, G.A., Best, E.A., Martinetti, C. and Nester, E.W. (1991). Genetic analysis of Agrobacterium tumefaciens. Methods in Enzymology 145:177-181.

Cangelosi, G.A., Martinetti G, Leigh J.A., Lee, C.C., Theines, C. and Nester, E.W. (1989). Role of Agrobacterium tumefaciens chvA protein in export of $\beta-1,2$ glucan. Journal of Bacteriology 171:1609-1615.

Cangelosi, G.A., Ankenbauer, R.G., and Nester, E.W. (1990). Sugars induce the Agrobacterium virulence genes through a periplasmic binding protein and a transmembrane signal protein. Proceedings of the National Academy of Sciences USA 87:6708-6712.

Chang, CH and Winans, S.C. (1992). Functional roles assigned to the periplasmic, linker and receiver domains of the Agrobacterium tumefaciens VirA protein. Journal of Bacteriology 174:7033-7039.

Cheng, M, Fry, J.E., Pang, S.Z., Zhou, H.P., Hironaka, C.M., Duncan, D.R., Conner, W. and Wan, Y.C. (1997). Genetic transformation of wheat mediated by Agrobacterium tumefaciens. Plant Physiology 115: 971980 .

Cheng, XY, Sardana, R., Kaplan, H. and Altosaar, I. (1998). Agrobacterium-transformed rice expressing synthetic cry $1 \mathrm{Ab}$ and cry1Ac genes are higly toxic to striped stem borer and yellow stem borer. Proceedings of the National Academy of Sciences USA 95:2767-2772.

Christie, P.J. (1997). Agrobacterium tumefaciens Tcomplex transport apparatus: a paradigm for a new family of multifunctional transporters in Eubacteria. Journal of Bacteriology 179: 3085-3094.

Dang, T.A.T. and Christie, P.J. (1997). The VirB4 ATPase of Agrobacterium tumefaciens is a cytoplasmic membrane protein exposed at the periplasmic surface. Journal of Bacteriology 179: 453-462. 
Das, A and Xie, Y.H. (1998). Construction of transposon Tn3phoA: its application in defining the membrane topology of the Agrobacterium tumefaciens DNA transfer proteins. Molecular Microbiology 27: 405-414.

De la Pena, A, Lörz, H.and Schell, J.(1987). Transgenic rye plants obtained by injecting DNA into young floral tillers. Nature 325:274-276.

Deblaere, R., Bytebier, B., De Greve, H., Deboeck, F., Schell, J., Van Montagu, M. and Leemans, J. (1985). Efficient octopine $\mathrm{Ti}$ plasmid-derived vectors for Agrobacterium-mediated gene transfer to plants. Nucleic Acid Research 13: 4777-4788.

Doty, SL, Yu, N.C., Lundin, J.I., Heath, J.D. and Nester, E.W. (1996). Mutational analysis of the input domain of the VirA protein of Agrobacterium tumefaciens. Journal of Bacteriology 178: 961-970.

Douglas C.J., Halperin, W.and Nester, E.W. (1982). Agrobacterium tumefaciens mutants affected in attachment to plant cell. Journal of Bacteriology 152:1265-1275.

Dürrenberger, F., Crameri, A., Hohn, B. and KoukolikovaNicola, Z. (1989). Covalently bound VirD2 protein of Agrobacterium tumefaciens protects the T-DNA from exonucleolytic degradation. Proceedings of the National Academy of Sciences USA 86:9154-9158.

Enríquez-Obregón, G.A., Vázquez-padrón, R.I., Prietosansonov, D.L., de la Riva, G.A. and SelmanHousein,G.(1998). Herbicide resistant sugarcane (Saccharum officinarum L.) plants by Agrobacteriummediated transformation. Planta 206:20-27.

Enríquez-Obregón, G.A., Vázquez-Padrón, R.I., PrietoSamsónov, D.L., Pérez, M. and Selman-Housein, G. (1997). Genetic transformation of sugarcane by Agrobacterium tumefaciens using antioxidants compounds. Biotecnología Aplicada 14:169-174

Fernández, D., Spudich, G.M., Zhou, X.R., Berger, B.R. and Christie, P.J. (1996). Agrobacterium tumefaciens VirB7 lipoprotein is required for stabilization of VirB proteins during assembly of the T-complex transport apparatus. Journal of Bacteriology 178:3168-3176.

Filichkin, SA and Gelvin,S.B. (1993). Formation of a putative relaxation intermediate during T-DNA processing directed by Agrobacterium tumefaciens VirD1/D2 endonuclease. Molecular Microbiology 8: 915-926.

Finberg , K.E., Muth, T.R. Young, S.P., Maken, J.B., Heitritter, S.M., Binns, A.N. and Banta, L.M. (1995). Interactions of VirB9, -10 and -11 with the membrane fraction of Agrobacterium tumefaciens: solubility studies provide evidence of tight associations. Journal of Bacteriology 177:4881-4889.

Firth, N., Ippen-Ihler, K. and Skurray, R.A. (1996). Structure and function of the $\mathrm{F}$ factor and mechanism of conjugation, p. 2377-2401. In: FC Neidhardt, R Curtis III, JL Ingraham, ECC Lin, KB Low, B Magasanik, WS Reznikoff, M Riley, M Schaechter and HC Umbarger (ed.), Escherichia coli and Salmonella: cellular and molecular biology $2^{\text {nd }}$ edition. American Society for Microbiology. Washington DC.

Fromm, M., Taylor, L. and Walbot, V. (1985). Expression of genes transferred into monocotyledonous and dicotyledonous plant cells by electroporation. Proceedings of the National Academy of Sciences USA 82:5824-5828.

Fromm, M, L Taylor and V Walbot (1986). Stable transformation of maize after gene transfer by electroporation. Nature 319:791-793.

Fullner, K.J., Lara, J.C. and Nester, E.W. (1996). Pilus assembly by Agrobacterium T-DNA transfer genes. Science 273:1107-1109.

Gallo-Meagher, M. and Irvine, J.M. (1996). Herbicide resistant transgenic sugarcane plants containing the bar gene. Crop Science 36: 1367-1374.

Gheysen, G., Villarroel, R. and Van Montagu, M. (1989). Illegitimate recombination in plants: a model for T-DNA integration. Genes Development 5:287-297.

Hamilton, C.M. (1997) A binary-BAC system for plant transformation with high-molecular-weight DNA. Gene 200:107-116.

Hansen, G., Shillito, R.D. and Chilton, M.D. (1997). Tstrand integration in maize protoplasts after codelivery of a T-DNA substrate and virulence genes. Proceedings of the National Academy of Sciences USA 94:11726-11730.

Heath, J.D., Charles, T.C. and Nester, E.W. (1995). Ti plasmid and chromosonally encoded two-component systems important in plant cell transformation by Agrobacterium tumefaciens, p. 367-385. In: JA Hoch and TJ Silhavy (ed.), Two-component signal transduction. ASM Press, Washington DC.

Heinemann, J.A. and Sprague, G.F. (1989). Bacterial conjugative plasmids movilize DNA transfer between bacteria and yeast. Nature 340:205-209.

Herrera-Estrella, A., Van Montagu, M. and Wang, K. (1990). A bacterial peptide acting as a plant nuclear targeting signal: the amino-terminal portion of Agrobacterium VirD2 protein directs the $\beta$-galactosidase 
fusion protein into tobacco nuclei. Proceedings of the National Academy of Sciences USA 87:9534-9537.

Herrera-Estrella, L. (1983). Transfer and expression of foreign genes in plants. $\mathrm{PhD}$ thesis. Laboratory of Genetics, Gent University, Belgium.

Hiei, Y., Ohta, S., Komari, T. and Kumashiro, T. (1994). Efficient transformation of rice (Oriza sativa) mediated by Agrobacterium and sequence analysis of the boundaries of the T-DNA. The Plant Journal 6: 271-282

Higgings, C.F., Hyde, S.C., Mimmack, M.M., Gileadi, U., Gill, D.R. and Gallagher, M.P. (1990). Binding proteindependent transport systems. Journal of Bioenergy and Biomembranes 22:571-592.

Hille, J., Wullems, G. and Schilperoort, R.A. (1983). Nononcogenic T-region mutants of Agrobacterium tumefaciens do transfer T-DNA into plant cells. Plant Molecular Biology 2:155-163.

Hooykaas, P.J.J. and Shilperoort, R.A. (1992). Agrobacterium and plant genetic engineering. Plant Molecular Biology 19:15-38.

Huang, Y., Morel, P., Powell, B. and Kado, C.I. (1990). VirA, a coregulator of Ti-specified virulence genes, is phosphorylated in vitro. Journal of Bacteriology 172:11421144.

Ishida, Y., Saito, H., Ohta, S., Hiei, Y., Komari, T., and Kumashiro, T. (1996). High efficiency transformation of maize (Zea mayz L.) mediated by Agrobacterium tumefaciens. Nature Biotechnology 4: 745-750

Iuchi, S. (1993). Phosphorylation/dephosphorylation of the receiver module at the conserved aspartate residue controls transphosphorylation activity of histidine kinase in sensor protein ArcB of Escherichia coli. Journal of Biological Chemistry 268:23972-23980.

Jayaram, M. (1994). Phosphoryl transfer if FLP recombination: a template for strand transfer mechanisms. Trends Biotechnology. 19:78-82.

Jefferson, R.A. (1987). Assaying chimeric genes in plants: the genes fusion system. Plant Molecular Biology Report $5: 387-405$

Jeon, G.A., Eum, J.S. and Sim, W.S. (1998). The role of inverted repeat (IR) sequence of the virE gene expression in Agrobacterium tumefaciens pTiA6. Molecules and Cells 8:49-53.

Jin, S., Prusti, R.K., Roitsch, T., Ankenbauer, R.G. and Nester, E.W. (1990a). The VirG protein of Agrobacterium tumefaciens is phosphorylated by the autophosphorylated
VirA protein and this is essential for its biological activity. Journal of Bacteriology 172:4945-4950.

Jin, S., Roitisch, T., Christie, P.J. and Nester, E.W. (1990b). The regulatory VirG protein specifically binds to a cis acting regulatory sequence involved in transcriptional activation of Agrobacterium tumefaciens virulence genes. Journal of Bacteriology 172:531-562.

Jin, S., Song, Y., Pan, S. and Nester, E.W. (1993). Characterization of a virG mutation that confers constitutive virulence gene expression in Agrobacterium tumefaciens. Molecular Microbiology 7:55-562.

Jones, A.L., Lai, E.M., Shirasu, K. and Kado, C.I. (1996). Vir B2 is a processed pilin-like protein encoded by the Agobacterium tumefaciens $\mathrm{Ti}$ plasmid. Journal of Bacteriology 178:5706-57112.

Kanemoto, R.H., Powell, A.T., Akiyoshi, D.E., Regier, D.A., Kerstetter, R.A., Nester, E.W., Hawes, M.C. and Gordon, M.P. (1989). Nucleotide sequence and analysis of the plant-inducible locus pinF from Agrobacterium tumefaciens. Journal of Bacteriology 171: 2506-2512.

Koncz, C., Németh, K., Redei, G.P. and Scell, J. (1994). In: p. 167-189, J Paszkowski (ed.). Homologous recombination and gene silencing in plants. Kluwer, Dordrecht, The Netherlands.

Kuldau, G.A., DeVos, G., Owen, J., McGaffrey, G. and Zambryski, P. (1990). The virB operon of Agrobacterium tumefaciens pTiC58 encodes 11 open reading frames. Molecular General Genetics 221: 256-266.

Lehman, C.W., Trautman, J.K. and Carroll, D. (1994). Illegitimate recombination in Xenopus: characterization of end-joined junctions. Nucleic Acid Research 22:434-442.

Lessl, M. and Lanka, E. (1994). Common mechanisms in bacterial conjugation and Ti-mediated T-DNA transfer to plant cells. Cell 77: 321-324.

Lessl, M., Balzer, D., Pansegrau,W. and Lanka, E. (1992). Sequence similarities between the RP4 Tra2 and the Ti VirB region strongly support the conjugation model for TDNA transfer. Journal of Biological Chemistry 267:2047120480.

Lörz, H., Baker, B. and Schell, J. (1985). Gene transfer to cereal cells mediated by protoplast transformation. Molecular General Genetics 199:473-497.

Martín, J.R., Gálvez, G., de Armas, R., Espinosa, R., Vigoa, R. and León, A. (1982). In: La caña de azúcar en Cuba. pp. 212-224. Editorial Científico Técnica, La Habana, Cuba. 
Matthysse A.G. (1987). Characterization of nonattaching mutants of Agrobacterium tumefaciens. Journal of Bacteriology 169:313-323.

Matthysse, A.G. (1983). Role of bacterial cellulose fibrils in Agrobacterium tumefaciens infection. Journal of Bacteriology 154:906-915.

Matthysse, A.G. (1986). Initial interactions of Agrobacterium tumefaciens with plant host cells. Critical Reviews in Microbiology 13:281-307.

Matthysse, A.G., Yarnall, H.A. and Young, N. (1996). Requirement for genes with homology to ABC transport system for attachment and virulence of Agrobacterium tumefaciens. Journal of Bacteriology 178:5302-5308.

May, G.D., Afza, R., Mason, H.S., Wiecko, A., Novak, F.J. and Arntzen, C.J. (1995). Generations of transgenic Banana (Musa acuminata) plants via Agrobacterium-mediated transformation. Bio/Technology 13:486-492

Menendez, R., Fernandez, S.I., Del-Rio, A., Gonzalez, R.M., Fraga, V., Amor, A.M., Mas, R.M. (1994). Policosanol inhibits cholesterol biosynthesis and enhances low density lipoprotein processing in cultured human fibroblasts. Biological Research. 27:199-203.

Nester, E.W., Gordon, M.P., Amasino, R.M. and Yanofsky, M.F. 1984). Crown gall: a molecular and physiological analysis. Annual Review of Plant Physiology 35:387-413.

Nixon, B.T., Ronson, C.W. and Ausubel, F.M. (1986). Two-component regulatory systems responsive to environmental stimuli share strongly conserved domains with the nitrogen assimilation regulatory genes $n t r B$ and $n t r C$. Proceedings of National Academy of Sciencess USA 83:7850-7854.

Oger, P., Kim, K.S., Sackett, S.L., Piper, K.R. and Farrand, S.K. (1998). Octopine-type Ti plasmids code for mannopine-inducible dominant-negative allele of TraR, the quorum-sensing activator that regulates Ti plasmid conjugal transfer. Molecular Microbiology 27:277-288.

Okamoto, S., Toyoda-Yamamoto, A., Ito, K., Takebe, I. and Machida,Y. (1991). Localization and orientation of the VirD4 protein of Agrobacterium tumefaciens in cell membrane. Molecular General Genetics 228:24-32.

Pan, S.Q., Charles, T., Jin, S., Wu, Z.L. and Nester, E.W. (1993). Preformed dimeric state of the sensor protein VirA is involved in plant-Agrobacterium signal transduction. Proceedings of the National Academy of Sciences USA 90:9939-9943.

Parkinson, J.S. (1993). Signal transduction schemes of bacteria. Cell 73: 857-871.
Patrau, J.M. (1989). By-products of the cane sugar industry. An introduction to their industrial utilization. In: Sugar Series 11, p. 435; Elsevier Science Publishers B.V., Amsterdam, Netherlands.

Peralta, E.G., and Ream, L.W. (1985). T-DNA border sequence required for crown gall tumorigenesis. Proceedings of the National Academy of Sciences USA 82:5112-5116.

Perl, A., Lotan, O., Abu-Abied, M. and Holland, D. (1996). Establishment of an Agrobacterium-mediated transformation system for grape (Vitis vinifera $\mathrm{L}$.): The role of antioxidants during the grape-Agrobacterium interactions. Nature Biotechnology 14:624-628

Piers, K.L., Heath, J.D., Liang, X., Stephens, K.M. and Nester, E.W. (1996). Agrobacterium tumefaciens-mediated transformation of yeast. Proceedings of the National Academy of Sciences USA 93:1613-1618.

Pohlman, R.F., Genetti, H.D. and Winans, S.C. (1994). Common ancestry between IncN conjugal transfer genes and macromolecular export systems of plant and animal pathogens. Molecular Microbiology 14:655-668.

Potrykus, I. (1991). Gene transfer to plants: Assessment of published approaches and results. Annu. Rev. Plant Physiol. Plant Molecular Biology 42:205-225

Puchta, H. (1998). Repair of genomic double-strand breaks in somatic cells by one-side invasion of homologous sequences. Plant Journal 13:331-339.

Rashid, H., Yokoi, S., Toriyama, K. and Hinata, K. (1996). Transgenic plant production mediated by Agrobacterium in Indica rice. Plant Cell Reports 15:727-730.

Rashkova, S., Spudlich, G.M. and Christie, P.J. (1997). Characterization of membrane and protein interaction determinants of the Agrobacterium tumefaciens VirB11 ATPase. Journal of Bacteriology 179: 583-591.

Rogowsky, P.M., Powell, B.S., Shirasu, K., Lim, T.S., Morel, P., Zyprian, E.M., Steck, T.R. and Kado, C.I. (1990). Molecular characterization of the vir regulon of Agrobacterium tumefaciens: complete nucleotide sequence and gene organization of the $28.63 \mathrm{kbp}$ regulon cloned as single unit. Plasmid 23: 85-106.

Rossi, L., Hohn, B. and Tinland, B. (1993). Vir D2 protein carries nuclear localization signals important to transfer of T-DNA to plants. Molecular General Genetics 239:345353.

Sanford, J. (1988). The biolistic process. Trends in Biotechnology 6:299-302. 
Seligman, L. and Manoil, C. (1994). An amphipathic sequence determinant of membrane protein topology. Journal of Biological Chemistry 269:19888-19896.

Shillito, R., Saul, M., Paszkowski, J., Muller, M. and Potrykus, I. (1985). High efficiency direct transfer to plants. Biotechnology 3:1099-1103.

Shimoda, N., Toyoda-Yamamoto, A., Nagamine, J., Usami, S., Katayama, M., Sakagami, Y. and Machida, Y. (1990). Control of expression of Agrobacterium tumefaciens genes by synergistic actions of phenolic signal molecules and monocaccharides. Proceedings of the National Academy of Sciences USA 87:6684-6688.

Shimoda, N., Toyoda-Yamamoto, A., Aoki, S. and Machida, Y. (1990). Genetic evidence for an interaction between the VirA sensor protein and the ChvE sugar binding protein of Agrobacterium tumefaciens. Journal of Biological Chemistry 268:26552-26558.

Shirasu, K., and Kado, C.I. (1993a). The virB operon of the Agrobacterium tumefaciens virulence regulon has sequence similarities to $\mathrm{B}, \mathrm{C}$, and $\mathrm{D}$ open reading frames downstream of the Pertussis toxin-operon and to the DNA transfer-operons of broad-host-range conjugative plasmids. Nucleic Acid Research 21:353-354.

Shirasu, K. and Kado, C.I. (1993b). Membrane location of the Ti plasmid VirB proteins involved in the biosynthesis of a pilin-like conjugative structure on Agrobacterium tumefaciens. FEMS Microbiology Letters 111:287-294.

Shirasu, K, Morel, P. and Kado, C.I. (1990). Characterization of the virB operon of an Agrobacterium tumefaciens $\mathrm{Ti}$ plasmid: nucleotide sequence and protein analysis. Molecular Microbiology 4:1153-1163

Shirasu, K., Koukolikova-Nicola, Z., Hohn, B. and Kado, C.I. (1994) An inner-membrane-associated virulence protein essential for T-DNA transfer from Agrobacterium tumefaciens to plants exhibits ATPase avtivity and similarities to conjugative transfer genes. Molecular Microbiology 11:581-588.

Shurvinton, C.E., Hodges, L. and Ream, W. (1992). A nuclear localization signal and the C-terminal omega sequence in the Agrobacterium tumefaciens VirD2 endonuclease are important for tumor formation. Proceedings of the National Academy of Sciences of the USA 89:11837-11841.

Smith, E.F. and Towsend, C.O. (1907). A plant tumor of bacterial origin. Science 25:671-673.

Spudich, G.M., Fernandez, D., Zhou, X.R. and Christie, P.J. (1996). Intermolecular disulfide bonds stabilize VirB7 homodimers and VirB7/VirB9 heterodimers during biogenesis of the Agrobacterium tumefaciens T-complex transport apparatus. Proceedings of the National Academy of Sciences USA 93:7512-7517.

Stephens, K.M., Roush, C. and Nester, E.W. (1995). Agrobacterium tumefaciens VirB11 protein requires a consensus nucleotide binding site for function in virulence. Journal of Bacteriology 177:27-36.

Sundberg, C., Meek, L., Carroll, K., Das, A. and Ream, W. (1996). VirE1 protein mediates export of the singlestranded DNA binding protein VirE2 from Agrobacterium tumefaciens into plant cells. Journal of Bacteriology 178:1207-1212.

Thomashow, M.F., Karlinsey, J.E., Marks, J.R. and Hurlbert, R.E. (1987). Identification of a new virulence locus in Agrobacterium tumefaciens that affects polysaccharide composition and plant attachment. Journal of Bacteriology 169:3209-3216.

Thompson, D.V., Melchers, L.S., Idler, K.B., Schilperoort, R.A. and Hooykaas, P.J.J. (1988). Analysis of the complete nucleotide sequence of the Agrobacterium tumefaciens virB operon. Nucleic Acids Research 16:4621-4636.

Tinland, B., Schoumacher, F., Gloeckler, V., Bravo, A.M., Angel, M. and Hohn, B. (1995). The Agrobacterium tumefaciens virulence D2 protein is responsible for precise integration of T-DNA into the plant genome. EMBO Journal 14:3585-3595.

Torisky, R.S., Kovacs, L., Avdiushko, S., Newman, J.D., Hunt, A.G. and Collins, G.B. (1997). Development of a binary vector system for plant transformation based on supervirulent Agrobacterium tumefaciens strain Chry5. Plant Cell Reports 17:102-108.

Toro, N., Datta, A., Carmi, O.A., Young, C., Prusti, R.K. and Nester, E.W. (1989) The Agrobacterium tumefaciens virCl gene products binds to overdrive, a T-DNA transfer enhancer. Journal of Bacteriology 171:6845-6849.

Turk, SCHJ., van Lange, R.P., Sonneveld, E. and Hooykaas, P.J.J. (1993). The chimeric VirA-Tar receptor protein is locked into highly responsive state. Journal of Bacteriology 175:5706-5709.

Uchimiya, H., Fushimi, T., Hashimoto, H., Harada, H., Syono, K. and Sugawara, Y. (1986). Expression of a foreign gene in callus derived from DNA-treted protoplasts of rice (Oryza sativa L.). Molecular General Genetics 204:204-207.

Van Haaren, M.J.J., Pronk, J.T., Schilperoort, R.A. and Hooykaas, P.J.J. (1987). Functional analysis of the Agrobacterium tumefaciens octopine Ti-plasmid left and right T-Region border fragments. Plant Molecular Biology 8:95-104. 
de la Riva, G. A., González-Cabrera, J., Vázquez-Padrón ,R., Ayra-Pardo, C.

Ward, J.E., Akiyoshi, D.E., Regier, D., Datta, A., Gordon, N.P. and Nester, E.W. (1988). Characterization of the virB operon from an Agrobacterium tumefaciens Ti plasmid. Journal of Biological Chemistry 265: 4768.

Whatley, M.H. and Spress, L.D. (1977). Role of bacterial lipopolysaccharide in attachment of Agrobacterium to moss. Plant Physiology 60: 765-766.

Winans, S.C. (1992). Two-way chemical signaling in Agrobacterium-plant interactions. Microbiology Reviews 56:12-31.
Zhou, X.R. and Christie, P.J. (1997). Suppression of mutant phenotypes of the Agrobacterium tumefaciens VcirB11 ATPase by overproduction of VirB proteins. Journal of Bacteriology 179:5835-5842.

Zupan, J.R. and Zambryski, P.C. (1995). Transfer of TDNA from Agrobacterium to the plant cell. Plant Physiology 107:1041.1047.

Zupan, J.R., Citovsky, V. and Zambryski, P.C. (1996). Agrobacterium VirE2 protein mediates nuclear uptake of single-stranded DNA in plant cells. Proceedings of the National Academy of Sciences USA 93: 2392-2397. 